\title{
Fungsi Ginjal pada Anak dengan Keganasan di RSUP H. Adam Malik Medan
}

\author{
Trie Hariweni, Bidasari Lubis, Rita Carmelia, Nelly Rosdiana, Adi Sutjïto
}

\begin{abstract}
Berbagai keganasan hematologi dan tumor padat mampu mempengaruhi fungsi ginjal. Komplikasi pada ginjal ini dapat terjadi selama perjalanan penyakit keganasan, akibat invasi keganasan pada ginjal, ureter, kandung kemih, akibat metabolit tumor tersebut serta akibat kemoterapi. Penelitian ini merupakan laporan pendahuluan yang bertujuan untuk mengetahui keadaan fungsi ginjal pada anak dengan keganasan, hal tersebut diperlukan dalam pertimbangan pemberian kemoterapi. Penelitian ini bersifat deskriptifrestropektif, data diambil dari rekam medik semua anak rawat inap yang menderita keganasan dan belum pernah mendapat kemoterapi, di Bagian IKA RS Adam Malik Medan dalam rentang waktu Januari 1997 sampai dengan Desember 2000. Fungsi ginjal dinilai dari laju filtrasi glomerulus. Diperoleh sampel penelitian 127 pasien, usia kurang dari 5 tahun terdiri dari $22(17 \%)$ pasien keganasan hematologi dan $42(33 \%)$ pasien tumor padat ganas, sedangkan usia lebih dari 5 tahun terdiri dari 41 (33\%) pasien keganasan hematologi dan $22(17 \%)$ pada pasien tumor padat ganas. Dari 127 pasien tersebut 63 pasien mengalami keganasan hematologi terdiri dari 43 laki-laki (34\%) dan 20 perempuan (16\%), sedangkan 64 pasien menderita tumor padat ganas terdiri dari 29 laki-laki (23\%) dan 35 perempuan (27\%). Keganasan hematologi dengan fungsi ginjal normal didapatkan pada 48 (38\%) anak, IRF (impaired renal function) 9 (14,3\%), CRI (chronic renal insufficiency) $6(9,5 \%)$ sedangkan pada tumor padat ganas dengan fungsi ginjal normal $52(41 \%)$, IRF $5(7,8 \%)$, CRI 2 (3,2\%), CRF (chronic renal failure) 5 $(8 \%)$. Terlihat bahwa pada pasien dengan keganasan hematologi dan tumor padat mengalami gangguan fungsi ginjal pada perjalanan penyakitnya.
\end{abstract}

Kata kunci : laju filtrasi glomerolus, penyakit keganasan.

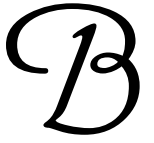

eberapa dekade terakhir ini, prognosis kanker pada anak mengalami perbaikan sehingga diperlukan pengenalan dini dan penanganan komplikasi terhadap organ vital yang mungkin timbul pada keganasan tersebut. ${ }^{1}$

Adanya komplikasi keganasan pada ginjal telah dilaporkan oleh beberapa penulis. ${ }^{2-7}$ Post (1961) dan Yolken (1976) melaporkan adanya gangguan fungsi ginjal pada leukemia. ${ }^{2-3}$ Windiastuti, dkk (2000)

\footnotetext{
Alamat korespondensi: Dr.Trie Hariweni, Sp.A.

Bagian Ilmu Kesehatan Anak, Fakultas Kedokteran Universitas Sumatera Utara / RS. H. Adam Malik Jl. Bunga Lau no. 17 Medan.

Telepon: 061-8360405, 8360143, 836034 Fax: 061-8361721.
}

melaporkan tiga kasus gagal ginjal akut dari 164 kasus LLA (leukemia limfosit akut). ${ }^{4}$ Hyman (1973) menemukan adanya lesi glomerulus pada pasien dengan penyakit Hodgkin dan limfoma Burkitt. ${ }^{6}$ Sedangkan Kiely (1969) melaporkan adanya komplikasi ginjal pada pasien limfoma. ${ }^{7}$ Gangguan fungsi ginjal tersebut bisa terjadi sebagai akibat sindrom lisis tumor dengan segala akibatnya ${ }^{1,8}$ invasi langsung ke ginjal, sistem vaskularisasi atau sistem pengumpulnya, produk hormon ${ }^{8,9}$ serta respon imunologis pasien terhadap tumor. ${ }^{10}$ Sebelum terapi definitif keganasan diberikan, kondisi pasien harus stabil, ${ }^{1}$ selain itu obat antineoplasma banyak bersifat nefrotoksik, ${ }^{11-13}$ sehingga diperlukan pemeriksaan fungsi ginjal sebelum pemberian kemoterapi. Secara praktis fungsi ginjal dapat dinilai dengan memperkirakan laju 
filtrasi glomerulus melalui pemeriksaan kreatinin serum. $^{14-15}$

Penelitian ini bertujuan untuk mengetahui keadaan fungsi ginjal yang dinilai dari laju filtrasi glomerulus melalui pemeriksaan kreatinin serum pada anak yang menderita keganasan di Sub Bagian HematologiOnkologi Bagian Ilmu Kesehatan Anak FK-USU / RS HAM-Medan.

\section{Bahan dan Cara}

Penelitian ini dilakukan secara deskriptif-restropektif, sampel didapat dari catatan medik pasien baru keganasan yang datang ke Subbagian Hemato Onkologi bagian IKA RS HAM Medan pada periode Januari 1997 sampai dengan Desember 2000.

Kriteria inklusi adalah semua pasien yang didiagnosis sebagai penyakit keganasan, berusia 1 bulan sampai dengan 15 tahun, dan belum pernah mendapat kemoterapi. Sedangkan kriteria ekslusi adalah bayi atau anak yang mengalami dehidrasi akibat penyakit penyerta, bayi atau anak yang mendapat obat-obatan yang mempengaruhi laju filtrasi glomerulus (vasokontriktor, vasodilator, dll), dan data tidak lengkap.

Data yang dicatat meliputi usia, jenis kelamin, panjang badan/tinggi badan, berat badan, diagnosis penyakit, kreatinin serum. Sedangkan fungsi ginjal dinilai dari laju filtrasi glomerulus (LFG) dengan rumus $^{14}$

\section{$\mathrm{KxTB}(\mathrm{cm}) \quad=\mathrm{LFG} \mathrm{ml} / \mathrm{menit} / 1,73 \mathrm{~m}^{2}$ Kreatinin plasma (mg/dl)}

$\mathrm{K}=$ Konstanta, nilai sesuai kelompok umur ${ }^{15}$

Selanjutnya hasil LFG disesuaikan dengan nilai normal LFG menurut umur ${ }^{15}$

Gangguan fungsi ginjal diklasifikasikan sebagai berikut $^{16}$

- Impaired renal function, jika fungsi ginjal 50 - 75\%

- Chronic renal insufficiency, jika fungsi ginjal 25 $50 \%$

- Chronic renal failure, jika fungsi ginjal 12,5-25\%

- End stage renal disease, jika fungsi ginjal < 12,5\%

Seluruh data yang diperoleh dicatat dan disajikan secara deskriptif.

\section{Hasil}

Selama periode Januari 1997 sampai Desember 2000 di Sub bagian Hemato-Onkologi Bagian Ilmu Kesehatan Anak FK-USU, Medan ditemukan pasien baru yang memenuhi kriteria inklusi sebanyak 127 kasus, yang terdiri dari 63 kasus keganasan hematologi dan 64 kasus tumor padat ganas. Jumlah anak lakilaki 72 (57\%) dan perempuan 55 (43\%) anak. Rentang usia antara 1 bulan sampai dengan 14 tahun 6 bulan. Dari Tabel 1 terlihat bahwa jumlah pasien berusia di bawah 5 tahun 64 anak (50\%) dan berusia di atas 5 tahun 63 anak (50\%). Pada kelompok keganasan hematologi didapatkan anak yang berusia di bawah 5 tahun sebanyak $22(17 \%)$ dan di atas 5 tahun 41 (33\%). Pada kelompok tumor padat ganas jumlah pasien yang berusia di bawah 5 tahun 42 anak (33\%) dan berusia di atas 5 tahun 22 anak (17\%).

Status gizi pasien keganasan hematologi terbanyak adalah gizi buruk berdasarkan berat badan menurut umur $(\mathrm{BB} / \mathrm{U})$ sebanyak 21 anak (17\%). Status gizi berdasarkan tinggi badan menurut umur $(\mathrm{TB} / \mathrm{U})$ dan berat badan menurut tinggi badan $(\mathrm{BB} / \mathrm{TB})$ tidak banyak berbeda. Pada kelompok tumor padat ganas status gizi berdasarkan $\mathrm{BB} / \mathrm{U}, \mathrm{TB} / \mathrm{U}$ maupun $\mathrm{BB} / \mathrm{TB}$ tidak banyak berbeda.

Pada Tabel 2 dapat dilihat distribusi jenis keganasan dan fungsi ginjal. Pada kelompok pasien keganasan hematologi 48 (38\%) anak mempunyai fungsi ginjal normal, dan 15 (12\%) anak mengalami gangguan fungsi ginjal. Dari kelompok pasien tumor padat ganas sebanyak $52(41 \%)$ anak mempunyai fungsi ginjal normal dan 12 anak (9\%) mengalami gangguan fungsi ginjal.

Tabel 3 memperlihatkan bahwa kasus keganasan hematologi yang terbanyak adalah leukemia limfositik akut yaitu sebanyak $39(61,8 \%)$ anak, 29 (46\%) anak di antaranya mempunyai fungsi ginjal normal, 6 (9,5\%) anak mengalami IRF, 4 (6,3\%) anak mengalami CRI. Pasien limfoma didapatkan sebanyak 9 (14,3\%) anak, $7(11,1 \%)$ anak mempunyai fungsi ginjal normal dan $2(3,2 \%)$ anak mengalami gangguan fungsi ginjal. Ditemukan 1 kasus mieloma multipel dengan IRF.

Tabel 4 memperlihatkan distribusi tumor padat ganas dan fungsi ginjal. Ditemukan kasus terbanyak adalah keganasan mata, yaitu retinoblastoma 20 (31\%) kasus, dengan 18 (28\%) anak di antaranya mempunyai fungsi ginjal normal dan 2 (3\%) anak mengalami IRF. Pasien tumor ginjal dan genitourinaria ditemukan 6 
Sari Pediatri, Vol. 3, No. 2, September 2001

Tabel 1. Karakteristik pasien keganasan

\begin{tabular}{|c|c|c|c|c|c|c|}
\hline \multirow{3}{*}{ Karakteristik } & \multicolumn{4}{|c|}{ Keganasan } & \multirow{3}{*}{ Total } & \multirow{3}{*}{$\%$} \\
\hline & \multicolumn{2}{|c|}{ Hematologi } & \multicolumn{2}{|c|}{ Tumor padat } & & \\
\hline & $\mathrm{n}$ & $\%$ & $\mathrm{n}$ & $\%$ & & \\
\hline \multicolumn{7}{|l|}{ Jenis kelamin } \\
\hline Laki-laki & 43 & 34 & 29 & 23 & 72 & 57 \\
\hline Perempuan & 20 & 16 & 35 & 27 & 56 & 43 \\
\hline \multicolumn{7}{|l|}{ Usia (tahun) } \\
\hline$<5$ & 22 & 17 & 42 & 33 & 64 & 50 \\
\hline$\geq 5$ & 41 & 33 & 22 & 17 & 63 & 50 \\
\hline \multicolumn{7}{|c|}{ Status gizi berdasar 'Z' Skor } \\
\hline \multicolumn{7}{|c|}{$\mathrm{BB} / \mathrm{U}$} \\
\hline Baik & 10 & 8 & 19 & 15 & 29 & 23 \\
\hline Sedang & 15 & 12 & 16 & 12 & 31 & 24 \\
\hline Kurang & 17 & 13 & 14 & 11 & 31 & 24 \\
\hline Buruk & 21 & 17 & 15 & 12 & 36 & 29 \\
\hline \multicolumn{7}{|l|}{$\mathrm{TB} / \mathrm{U}$} \\
\hline Baik & 20 & 16 & 22 & 17 & 42 & 33 \\
\hline Sedang & 10 & 8 & 12 & 9 & 22 & 17 \\
\hline Kurang & 12 & 9 & 15 & 12 & 27 & 21 \\
\hline Buruk & 21 & 17 & 15 & 12 & 36 & 29 \\
\hline \multicolumn{7}{|l|}{ BB/TB } \\
\hline Baik & 15 & 12 & 20 & 16 & 35 & 28 \\
\hline Sedang & 13 & 10 & 15 & 12 & 28 & 22 \\
\hline Kurang & 14 & 11 & 9 & 6 & 23 & 17 \\
\hline Buruk & 21 & 17 & 20 & 16 & 41 & 33 \\
\hline
\end{tabular}

Tabel 2. Distribusi jenis keganasan dan fungsi ginjal

\begin{tabular}{|c|c|c|c|c|c|c|}
\hline \multirow{3}{*}{ Jenis keganasan } & \multicolumn{4}{|c|}{ Fungsi ginjal } & \multirow{3}{*}{ Total } & \multirow{3}{*}{$\%$} \\
\hline & \multicolumn{2}{|c|}{ Normal } & \multicolumn{2}{|c|}{ Tidak normal } & & \\
\hline & $\mathrm{n}$ & $\%$ & $\mathrm{n}$ & $\%$ & & \\
\hline Hematologi & 48 & 38 & 15 & 12 & 63 & 50 \\
\hline Tumor padat & 52 & 41 & 12 & 9 & 64 & 50 \\
\hline Total & 100 & 79 & 27 & 21 & 127 & 100 \\
\hline
\end{tabular}

$(9,4 \%)$ kasus, hanya $2(3,2 \%)$ anak yang mengalami gangguan fungsi ginjal. Sarkoma jaringan lunak ditemukan $5(7,8 \%)$ kasus dan yang mengalami gangguan fungsi ginjal sebanyak $2(3,2 \%)$ anak. Keganasan syaraf simpatis ditemukan 4 (6,2\%) kasus dan hanya 1 anak dengan gangguan fungsi ginjal. Keganasan hati dan tulang masing-masing 1 kasus dan keduanya tidak mengalami gangguan fungsi ginjal.

\section{Diskusi}

Selama bulan Januari 1997 sampai dengan Desember 2000 ditemukan 127 anak yang memenuhi kriteria 
Sari Pediatri, Vol. 3, No. 2, September 2001

Tabel 3. Distribusi keganasan hematologi dan fungsi ginjal

\begin{tabular}{|c|c|c|c|c|c|c|c|c|c|c|}
\hline \multirow{3}{*}{ Jenis keganasan } & \multicolumn{8}{|c|}{ Fungsi Ginjal } & \multirow{3}{*}{ Total } & \multirow{3}{*}{$\%$} \\
\hline & \multicolumn{2}{|c|}{ Normal } & \multicolumn{2}{|c|}{ IRF } & \multicolumn{2}{|c|}{ CRI } & \multicolumn{2}{|c|}{ CRF } & & \\
\hline & $\mathrm{n}$ & $\%$ & $\mathrm{n}$ & $\%$ & $\mathrm{n}$ & $\%$ & $\mathrm{n}$ & $\%$ & & \\
\hline LLA* & 29 & 46,0 & 6 & 9,5 & 4 & 6,3 & 0 & 0 & 39 & 61,8 \\
\hline LNLA** $^{* *}$ & 9 & 14,3 & 1 & 1,6 & 1 & 1,6 & 0 & 0 & 11 & 17,5 \\
\hline $\mathrm{LMA}^{* * *}$ & 3 & 4,8 & 0 & 0 & 0 & 0 & 0 & 0 & 3 & 4,8 \\
\hline \multicolumn{11}{|l|}{ Limfoma } \\
\hline - Non Hodgkin & 6 & 9,5 & 1 & 1,6 & 1 & 1,6 & 0 & 0 & 8 & 12,7 \\
\hline • Burkitt & 1 & 1,6 & 0 & 0 & 0 & 0 & 0 & 0 & 1 & 1,6 \\
\hline Mieloma multipel & 0 & 0 & 1 & 1,6 & 0 & 0 & 0 & 0 & 1 & 1,6 \\
\hline Total & 48 & 76,2 & 9 & 14,3 & 6 & 9,5 & 0 & 0 & 63 & 100 \\
\hline
\end{tabular}

penelitian. Dari 127 pasien tersebut, 63 (50\%) anak menderita keganasan hematologi dan 64 (50\%) anak menderita tumor padat ganas. Pada keganasan hematologi jumlah pasien laki-laki 43 (34\%) anak dan perempuan $20(16 \%)$ anak. Pizzo menyatakn perbandingan laki-laki dan perempuan pada LLA adalah $1: 3{ }^{17}$ Pada kelompok pasien tumor padat ganas ditemukan 29 (23\%) anak laki-laki dan 35 anak (27\%) perempuan. Ellsworth menyatakan bahwa predileksi retinoblastoma tidak tergantung pada jenis kelamin. ${ }^{18}$ Rentang usia berkisar antara 1 bulan sampai dengan 14 tahun 6 bulan. Keganasan hematologi lebih banyak berusia di atas 5 tahun yaitu $41(33 \%)$ anak sedangkan yang berusia di bawah 5 tahun sebanyak $22(17 \%)$ anak. Pizzo menyatakan bahwa puncak insiden untuk LLA berusia sekitar 4 tahun. ${ }^{17}$ Tumor padat ganas lebih banyak ditemukan pada usia di bawah 5 tahun yaitu sebanyak 42 (33\%) anak sedangkan pasien yang berusia di atas 5 tahun sebanyak $22(17 \%)$ anak. Pizzo menyatakan bahwa insiden tumor padat ganas rata-rata di bawah usia 15 tahun. ${ }^{19-21}$

Pada pasien keganasan hematologi paling banyak mengalami gangguan gizi secara akut, terlihat dari status gizi berdasarkan berat badan menurut umur (BB/U) berdasarkan baku NCHS-WHO, yaitu sebanyak $21(17 \%)$ anak. Sedangkan pada tumor padat ganas yang mengalami gizi buruk menurut $\mathrm{BB} /$ U hanya15 (12\%) anak. Jika status gizi kurang dan buruk digabung maka ditemukan $29(23 \%)$ anak. Hal ini sesuai dengan beberapa kepustakaan yang menyatakan adanya gangguan gizi pada pasien keganasan akibat berbagai faktor antara lain asupan yang kurang dan akibat penyakit keganasan yang dideritanya. ${ }^{22}$

Dari hasil penelitian ini ditemukan bahwa 79\% kasus keganasan hematologi dan tumor padat masih mempunyai fungsi ginjal normal. Kemungkinan karena mereka datang saat dini sehingga belum terjadi komplikasi pada ginjal. ${ }^{1,17,23}$

Pada penelitian ini penulis hanya menyajikan data secara deskriptif dan tidak mencari penyebab pasti terjadinya gangguan fungsi ginjal pada keganasan hematologi maupun tumor padat. Untuk itu perlu dilakukan penelitian lebih lanjut untuk mencari penyebab gangguan fungsi ginjal pada kasus keganasan.

\section{Ringkasan}

Telah dilakukan penelitian deskriptif retrospektif terhadap anak yang menderita penyakit keganasan hematologi dan tumor padat selama kurun waktu Januari 1997 sampai dengan Desember 2000. Diperoleh 127 sampel penelitian yang memenuhi kriteria inklusi, terdiri dari 63 kasus keganasan hematologi dengan 15 (12\%) anak yang mengalami gangguan fungsi ginjal dan 64 kasus tumor padat ganas dengan 12 (9\%) anak yang mengalami gangguan fungsi ginjal. Pada penelitian ini tidak diketahui secara pasti mekanisme terjadinya gangguan fungsi ginjal pada keganasan. Untuk itu diperlukan penelitian lanjutan untuk mencari mekanisme penyebab gangguan fungsi ginjal pada kasus keganasan dengan metode penelitian prospektif. 


\section{Daftar Pustaka}

1. Kelly KM, Lange B. Oncologic emergencies. Dalam: Orlowski JP, penyunting. Pediatric clinic of North America. Philadelphia: Saunders, 1997; 44. h. 809.

2. Post J. Anuria as a presenting symptom in unsuspected leukimia. N Engl J Med 1961; 264. h. 1253-4.

3. Yolken RH, Miller DR. Hyperuricemia and renal failure presenting manifestations of occult hematologic malignancies. J Pediatric 1976; 89:775-7.

4. Windiastuti E, Abdulsalam M, Pudjiastuti P, Amalia P, Gatot D. Renal failure as initial presentation of childhood acute lymphoblastic leukimia: case report. Dipresentasikan pada $1^{\text {st }}$ SIOP-ASIA congress. Singapura 2000.

5. Ellman L, Davis J, Lichtenstein NS. Uremia due to occult lymphomatous infiltration of the kidneys. Cancer 1974; 33:203-5.

6. Hyman LR, Burkholder PM, Joo PA, Segar WE. Malignant lymphoma and nephrotic syndrome. J Pediatric 1973; 82:207-17.

7. Kiely JM, Wagoner RD, Holley KE. Renal complications of lymphoma. Ann intern Med. 1969; 71: 1159-75.

8. Moorthy AV, Chesney RW. Renal and metabolic effects of extrarenal neoplasmas. Dalam: Edelmann CM, penyunting. Pediatric kidney disease. Edisi ke-2. Boston: Little, Brown, 1992. h. 1557-64.

9. Lundberg WB, Cadman ED, Finch SC,Capizzi RL. Renal failure secondary to leukemic infiltration of the kidneys. Am J Med 1977; 62:636-42.

10. Eagen and Lewes. Glomerulopathies of neoplasia. Kidneys Int 1997; 11:297-306.

11. Bleyer WA. Cancer chemotheraphy in infants and children. Dalam: Altman AJ, penyunting. The pediatric clinics of North America. Philadelphia: Saundres, 1985; 32. h. 557-70.

12. Blachley JD, Hill JB. Renal and electrolyte disturbances associated with cisplantin. Ann Intern Med 1981; 95:628-32.
13. Dentino M, Luft FC, Yum MN, Williams SD, Einhorn LH. Longterm effect of cis-diamminedichloride platinum (CDDP) on renal function and structure in man. Cancer 1978; 41:1274-81.

14. Alatas H. Evaluasi fungsi ginjal. Dalam: Alatas $H$, Tambunan T, Trihono PP, penyunting. Nefrologi anak. Jilid 1. Jakarta: Balai Penerbit FKUI, 1993. h. 33-51.

15. Kher KK. Evaluation of renal function. Dalam: Kher KK, Mekker SP, penyunting. Clinical pediatric nephrology. New York: Mc Graw-Hill, 1992. h. 3-22.

16. Gauthier B, Edelmann CM, Barnett HL. Nephrology and urology for the pediatrician. Boston: little, Brown, 1982. h. 193-203.

17. Margolin JF, Poplack DG. Acute lymphoblastic leukimia. Dalam: Pizzo PA, Poplack DG, penyunting. Principles and practice of pediatric oncology. Edisi ke-2. Philadelphia: Lippincott-Raven, 1997. h. 409-62.

18. Ellworth RM. The practical management of retinoblastoma. Trans Am Opthamol Soc 1969; 67:462-534.

19. Donaldson SS, Egbert PR, Newsham I, Cavanee WK, Retinoblastoma. Dalam: Pizzo PA, Poplack DG, penyunting. Principles and practise of pediatric oncology. Edisi ke-2 Philadelphia: Lippincott-Raven. 1997. h. 699.

20. Shad A, Magrath IT. Malignant non Hodgkin's lymphomas in children. Dalam: Pizzo PA, Poplack DG, penyunting. Principles and practise of pediatric oncology. Edisi ke-2 Philadelphia: Lippincott-Raven. 1997. h. 545.

21. Hudson MM, Donald SS. Hodgkin's disease. Dalam: Pizzo PA, Poplack DG, penyunting. Principles and practise of pediatric oncology. Edisi ke-2 Philadelphia: Lippincott-Raven. 1997. h. 523.

22. Alexander HR, Rickard KA, Godshall B. Nutritional Supportive Care. Dalam: Pizzo PA, Poplack DG, penyunting. Principles and practise of pediatric oncology. Edisi ke-2 Philadelphia: Lippincott-Raven. 1997. h. 1167-813.

23. Mayne PD. Clinical chemistry in diagnosis and treatment. Edisi ke-6. England: ELBS, 1994. h. 366-8. 